\title{
REVIEWS
}

\section{MacKinnon's Feminism: Power on Whose Terms?}

\author{
FEMINISM UNMODIFIED: Discourses ON LIFE AND LAw. By Catha- \\ rine A. MacKinnon. $\dagger$ Cambridge and London: Harvard University \\ Press 1987. Pp. 315 . $\$ 25.00$.
}

Reviewed by Katharine T. Bartlettf

I

Catharine MacKinnon writes about power-about who has it, how they keep it, and why those who don't have it should want it and get it. Like Karl Marx, she has a complete explanation for it, a "total" theory of power to account for "how a systematically unequal social arrangement ... is internally coherent and internally rational and pervasive yet unjust" (p. 49). Her theory is this: men have power over everything of value in society, even the power to decide what has value and what does not. Men use this power systematically to shape and define the social beings we call men and women in ways which enhance the power of men and keep women subordimate to men. How men have constructed the relationship between men and women in turn shapes and constructs society $^{1}$ as a whole such that each of its constitutive parts-its law, its institutions, the private relationships it fosters-is organized hierarchically, by sex. Women, in short, have been had and will continue to be had (in every sense) until we understand our trap, seize the power to control our own lives, and get men's feet "off our necks" (p. 45).

Feminism Unmodified is a collection of speeches delivered over a five-year period from 1981 to 1986 to both legal and nonlegal audiences. The format is effective, giving us the poetic anger and hard-driving sensitivity to women's plight of MacKinnon's spoken word, in hard copy we

$\dagger$ Visiting Scholar, Institute for Research on Women and Gender, Stanford University. B.A. 1969, Smith College; M.Phil. 1973, J.D. 1977, Yale University.

$\ddagger \quad$ Professor of Law, Duke University School of Law. B.A. 1968, Wheaton College; M.A. 1969, Harvard University; J.D. 1975, Boalt Hall School of Law, University of California, Berkeley.

1. MacKinnon notes that

Sexuality to feminism is, like work to marxism, socially constructed and at the same time constructing. .... As the organized expropriation of the work of some for the use of others defines the class, workers, the organized expropriation of the sexuality of some for the use of others defines the sex, woman (p. 49). 
can read and reread after we have given the emotional power of her voice a chance to wear off. The collection serves as a comprehensive and readable summary of the critique of American society and its legal system that has established her reputation as one of the most original and uncompromising of contemporary feminist thinkers. Those familiar with MacKinnon's work ${ }^{2}$ may find little here that is new. But for those who have had trouble getting through this work or those who have yet to immerse themselves in MacKinnon's theory of power, this book is a good place to start.

MacKinnon uses each occasion presented in these collected speeches to demonstrate that everything of relevance to women fits her theory of power. Every topic she takes on-women's inferior status in the workplace, sexual harassment, pornography, rape, family violence, the small number of successful women athletes-is an opportunity for her to demonstrate the coherence and rationality of a single system of oppression.

The key to this system of gendered hierarchy is the use by men of abstract standards and principles. These standards and principles appear to be gender-neutral, but in fact, according to MacKinnon, they are designed to create and maintain male advantage.

Men's physiology defines most sports, their needs define auto and health insurance coverage, their socially designed biographies define workplace expectations and successful career patterns, their perspectives and concerns define quality in scholarship, their experiences and obsessions define merit, their objectification of life defines art, their military service defines citizenship, their presence defines family, their inability to get along with each other-their wars and rulerships-defines history, their image defines god, and their genitals define sex (p. 36; see also pp. 71-72).

The use of neutral principles allows men to rationalize and legitimize their dominance over women. When women do not meet the standards set by men, their exclusion and inferior position are explained away as a consequence of their differences from men. This explanation, according to MacKinnon, distracts us from seeing that underlying these neutral standards is a man-made hierarchy structured on the basis of sex and stacked against women (pp. 36, 71-72).

MacKinnon draws heavily on the theme of pornography to demon-

2. MacKinnon's most notable foundational work includes C. MACKINNON, SExUAl. Harassment of Working Women: A CASE of SeX Discrimination (1979); MacKinnon, Feminism, Marxism, Method, and the State: Toward Feminist Jurisprudence, 8 SIGNS: J. WoMEN Culture \& Soc'y 636 (1983); and MacKinnon, Feminism, Marxism, Method, and the State: An Agenda for Theory, 7 Signs: J. WOMEN Culture \& Soc'Y 515 (1982). Some of the speeches in Feminism Unmodified have been published in other sources. See pp. 307-08. Those most frequently cited in the legal literature are MacKinnon, Not a Moral Issue, 2 YALE L. \& Pol'Y REv. 321 (1984), and MacKinnon, Pornography, Civil Rights, and Speech, 20 HARv. C.R.-C.L. L. REv. 1 (1985). 
strate her thesis that the whole of society is structured as a male hierarchy. Six of the sixteen essays are devoted specifically to pornography, and discussion of it runs heavily through most of the other essays as well. To MacKinnon, pornography plays a critical role in the systematic oppression of women. Pornography creates sexual reality for both men and women, setting the terms upon which men relate to women as subject to object. Pornography silences women, defining them as acquiescent in, indeed desirous of, violation and possession by men (p. 172). At the same time it eroticizes male violence against women and "institutionalizes the sexuality of male supremacy" (p. 172). Like abstract (1nale) principles of neutrality, equality, and justice, pornography hides what it is by calling it something else. "Pornography turns sex inequality into sexuality and turns male dominance into the sex difference" (p. 3). Because pornography so successfully constrncts social reality, it makes the harm of dominance and violence by men agamst women commonplace, assuring its invisibihty (p. 174).

MacKinnon rejects the prevailing legal strategies for improving the inferior position in which woinen find themselves. She finds both the "equal treatment" approach of hiberal feminists, which minimizes differences between men and women as a basis for demanding equal treatment, and the "special treatment" approach of more radical feminists, which argues for special benefits based on women's differences, fatally committed to the principle of difference. Such a commitment, she claims, merely perpetuates the male standards and values from which difference is measured (pp. 32-40, 71-77).

MacKinnon urges as an alternative what she calls the "dominance" approach. The dominance approach exposes the entire structure of our society as a gendered hierarchy, highlighting the extent to which women are specific victims of male hierarchy, not accidental misfits. It calls for not only the elimination of those impediments to women's success in the world on male terms, but the transforination of those terms themselves and the right of women to be judged by their own standards (pp. 44, 166$67,179)$.

MacKinnon attempts to demonstrate the superiority of her dominance approach by showing that the so-called gains of liberal feminism have strengthened rather than weakened male hegemony. She argues, for example, that the sexual revolution only appeared to free women from their repressed sexuality; sex remains defined in terms set by men (pp. 98, 143). MacKinnon sees abortion rights for women as a means of making women, who no longer can use the prospect of unwanted pregnancy as a reason to avoid sexual relations, more accessible to men rather than more autonomous (pp. 99, 144). Equal child custody laws mean women now lose custody of their children to men under "neutral" criteria, such as 
level of income and presence of nuclear family (p. 35). It seems the only progress made by women has been the recognition of sexual harassment at the workplace as sex discrimination and legal advances against domestic battery and marital rape (p. 1), and this progress has occurred, apparently, because these wrongs were attacked as creatures of hierarchyfrom the women's point of view, as assaults-rather than as personal episodes based on sex difference (pp. 103-07, 170).

Mackinnon is brilliant in exposing the irony of the terms of women's oppression. In describing the survival of women who reject and rise above male authority, for example, she explains how "the success of our survival is used to delegitimize what we have survived to say"; it can't be that bad if some women can rise above it (p. 131). She analyzes how the strategies necessary for women to survive in the male world-to play along and submit-are the opposite of those required to change it (p. 16). She criticizes the way in which the pervasiveness of sexual abuse is often used to argue for its inevitability; anything so common must be just the way things are (p. 221). And she explains how the degradation of women stigmatizes women to the point where that degradation is taken as evidence that there was nothing of value to which harm could be done; a raped or pornographed person is damaged goods hardly worth the respect a recognition of her harm would bring (pp. 13, 181). These insights are devastating; indeed, once we understand them, it is hard to imagine ever returning to our accustomed ways of thinking about the world.

\section{II}

Ellen DuBois has commented that the problem with MacKinnon's metaphysically perfect system is that it is unreal. ${ }^{3}$ Whether one explanation of the world can adequately explain the inequality faced by women who live in it is problematic, and MacKinnon's own attempt to do so contains clues that totality cannot be easily achieved. Contradictions permeate her descriptions of reality. For example, she attributes to women both an unshakable knowledge of reality and an infinite capacity to be duped. To dismiss Cartesian epistemological doubt about how we can know as a "male standpoint" (pp. 57-58), for example, she asserts that women know that they "are raped, battered, pornographed, defined by force, by a world that begins, at least, entirely outside [them]" (p. 57). But she also insists that men have succeeded in making women believe that sex is pleasure and that women are meant to bring pleasure to men, in order to prove that even ordinary sex is ordinarily coercive (pp. 85-92,

3. DuBois, Dunlap, Gilligan, MacKinnon \& Menkel-Meadow, Feminist Discourse, Moral Values, and the Law-A Conversation, 34 Buffalo L. Rev. 11, 70 (1985). 
159-61). Can both of these assertions be true? Can women both have a hold on the reality of their oppressed circumstances, and also be fooled by men to think that the way the world is is the way it's supposed to be?

Contradiction also runs through her attempts to make historical sense of the facts upon which she depends. She claims, for example, that because sexual harassment is so pervasive, it could not be recognized as discrimination in the male world (p. 115). On the other hand, she also explains that because so many women are victims of sexual harassment, it had to be considered real; there were too many victims to consider them all hysterical (p. 108). Which is it? Can the frequency of sexual harassment be the explanation of both its nonrecognition and also its recognition?

By someone more comfortable with ambivalence and paradox, these contrary assertions might be turned into opportunities for further elaborations of the subtleties and complexities of women's experience and oppression. Take the epistemological dilemma. An important part of women's experience (and undoubtedly the experience of at least some men as well) is the existence of contradictory truths. Integral to women's experience is knowing one thing on one level, and a different, inconsistent thing on another. We "know" that we are living on someone else's terms at the same time we "know" that sex is exciting, that achievement in the employment world is secondary to our families, that personal fulfillment depends upon the fulfillment of those around us, and all the rest that we have been taught. Knowledge can occur on different levels and in different parts of ourselves. Is not our ambivalence real? Might this ambivalence even be further evidence of men's fraud against women (deinonstrated ironically by its incompleteness)?

MacKinnon's failure to confront the inconsistencies in her own observations about the effect of the pervasiveness of sexual harassment likewise represents a missed occasion for exploring the paradoxical nature of her thesis of male dominance. It would seem that the conditions of oppression can both perpetuate that oppression and be used to end it. Most likely, sexual harassment came to be recognized for what it is because, through the work of MacKinnon and others, we came to understand that one meaning made more sense than another. More explicit exploration of the way in which hegemonic meanings can be turned inside out, especially an exploration that is freed from the constrictions of a "total" theory of unmitigated oppression, might help us to see how this works and how we might turn the conditions of oppression into tools for liberation. Given MacKinnon's brilliant insights into the ironies of male hierarchy, it is disappointing that she is not able to see 
and use the ironies of her own theory. ${ }^{4}$

MacKinnon's failure to acknowledge that not every fact related to women's experience neatly and unreservedly supports her thesis of male dominance not only reduces the persuasiveness of her work, but demonstrates an effort to control and objectify her subject that is characteristic of the male world she otherwise so firmly rejects. She manifests other characteristics along this line that are troublesome as well. Her posture is one of arrogance; hers is the only true feminisin (pp. 5, 49, 137). She claims to speak for all women (p. 169), yet dismisses in disgust as "collaborators" those who don't think and act in accordance with her own views (pp. 198-205, 216-28). ${ }^{5}$ She eschews qualifications and gives only grudging, infrequent recognition to exceptions to her thesis-the courageous woman judge (pp. 220, 305 n.5), the sympathetic male (pp. 189-90, 216), the powerless male (p. 52). Facts are loosely reported in support of her theory. ${ }^{6}$

She also distorts legal precedents to provide the desired support for the absolutisin of her theory. Perhaps the best example is her insistence that "[v]irtually every ounce of control that women won out of [the legalization of abortion] has gone directly into the hands of men-husbands, doctors, or fathers" (p. 101). It is true that Roe v. Wade ${ }^{7}$ and much of

4. One exception is her observation that women's "demand for self-determination will be taken as a demand for paternal protection and will therefore strengthen male power rather than undermine it" (p. 104).

5. MacKinnon seems to reserve her greatest contempt for those who would claim to be feminists. Her treatment of right-wing women (pp. 21-31, 226) is considerably gentler than that of women in the middle (pp. 16, 140-45, 205, 216-28) or further left (p. 305 n.6). For example, of Phyllis Schlafly, she says: "I am not saying that her finger near the nuclear trigger would make me feel particularly safe- just that by the standards set by the men in the job, she should [have been appointed to a position in the current administration]" (p. 30). Of women who call themselves feminists but side with pornographers, she says:

It keeps the value of the most exceptional women high to keep other women out and down and on their backs with their legs spread. I may be missing something, but I don't see a lot of women lawyers, feminist or otherwise, selling their asses on the street or looking for a pornographer with a camera in order to fulfill their sexual agency and I don't think it is because they are sexually repressed (p. 205).

And after describing a scene in which a radical feminist attorney challenged MacKinnon's analysis that all women are subordinate to men, MacKinnon says derisively: "And I understood with new clarity what conservative women have been trying to tell us about feminists" (p. 306 n.6).

6. She reports, for example, that only $7.8 \%$ of women in the United States have nor been sexually assaulted or harassed in their lifetime (see, e.g., pp. 6, 75, and 171). One must comb the book's endnotes to discover (except for a very partial description on p. 23) that her entire support for this statistic is a study of 930 random San Francisco households, and that this figure includes obscene phone calls and unwanted sexual advances on the street, as well as other forms of sexual abuse and harassment. Whether or not one feels that these forms of sexual harassment should be counted along with rape and sexual assault, the freewheeling use of this statistic without an explanation of its background is misleading.

7. 410 U.S. 113, 164 (1973) ("For the stage prior to approximately the end of the first trimester, the abortion decision and its effectuation must be left to the medical judgment of the pregnant women's attending physician.") 
the case law that has followed ${ }^{8}$ have defined the abortion right in terms of the decision of the woman and her physician. It is also true that access by poor women to abortions has not been secured as a matter of constitutional right. ${ }^{9}$ But in an age in which doctors are, by and large, willing to perform abortions, and in which funding for abortions is provided to poor women in many states, ${ }^{10}$ MacKinnon's pessimistic conclusion that women have gained virtually nothing in the way of access to abortion is surely overstated. And with respect to the power of husbands, in particular, the Supreme Court has flatly held that states may not condition the right of a woman to an abortion on the consent of her husband. ${ }^{11}$

MacKinnon's method, all too often, is one of rather unconstrained and misleading power moves. This method is symptomatic of a deeper problem with her work. Despite her brilliant analysis of the way power is exercised in the male hierarchy, MacKinnon has given inadequate attention to how power should be used. Indeed, she seems entirely uninterested in what women should do with power, should they ever get any.

8. See, e.g., City of Akron v. Akron Center for Reproductive Health, Inc., 462 U.S. 416, 42930 (1982) (during her first trimester, "a pregnant woman must be permitted, in consultation with her physician, to decide to have an abortion"); accord H. L. v. Matheson, 450 U.S. 398, 435 (1981) (Marshall, J., dissenting); Bellotti v. Baird, 443 U.S. 622, 651 n.31 (1979); Planned Parenthood of Central Missouri v. Danforth, 428 U.S. 52, 61 (1976).

9. Harris v. McRae, 448 U.S. 297 (1980) (upholding constitutionality of federal restrictions against funding of abortions); Williams v. Zbaraz, 448 U.S. 358 (1980) (holding state not constitutionally obliged to pay for abortions not funded by federal government); Poelker v. Doe, 432 U.S. 519 (1977) (upholding city's refusal to provide publicly financed hospital services for nontherapeutic abortions while providing such services for childbirth).

10. See Petersen, The Public Funding of Abortion Services: Comparative Developments in the United States and Australia, 33 INT'L \& COMP. L.Q. 158, 170 (1984) (reporting that in mid-1981, after enforcement of federal restrictions against federal funding of abortions, nine states were financing abortion services for the indigent of their states entirely out of their own funds, and courts in two other states struck down restrictive state laws prohibiting such funding); Relkin \& Solomon, Using State Constitutions to Expand Public Funding for Abortions: Throwing Away the Carrot with the Stick, 9 WOMEN's RTS. L. REP. 27, 32 n. 11, 33 (1986) (reporting that nine states and the District of Columbia fund all or most abortions, and courts in six additional states have found unconstitutional certain funding restrictions under their state constitutions; twelve states provide public funding if the woman's life is endangered, and twenty more provide payment where the pregnancy resulted from promptly reported rape or incest).

11. Planned Parenthood of Central Missouri v. Danforth, 428 U.S. 52, 69 (1976). MacKinnon, of course, knows about Danforth, but she refers to it only in a "but cf." addendum to a footnote citing two cases qualifying a minor's right to an abortion over the objection of her parents (p. 249 n.18). Neither of these two cases provides any meaningful support for her proposition. In one of them, the minors were supported by intervenor doctors, the state by intervenor parents (represented by a mother). Bellotti v. Baird, 443 U.S. 622 (1979). The other case upheld a Utah statute requiring parental notification before a doctor could perform an abortion for an unmarried minor living with and dependent upon her parents. In this case, the physician was willing to perform the abortion but for the Utah statute that prohibited him from doing so without parental notification. H. L. v. Matheson, 450 U.S. 398 (1981). MacKinnon might have found somewhat more useful for her proposition the Fifth Circuit decision in Scheinberg v. Smith, 659 F.2d 476, 48485 (5th Cir. Unit B. Oct. 1981), which upheld a Florida statute requiring notification and consultation with the woman's husband before an abortion could be obtained. 
Although occasionally MacKinnon seems to have a glimpse of what a world good for women might be like (see, e.g., p. 217), she most often dismisses any vision as "fantasy" (p. 221), and those who have one as idealist and elitist (p. 219). Her position is that instead of developing any prescriptions now for what women want (besides, simply, more power), we must wait and see who women are after they are no longer oppressed (pp. 45, 77). Over and over, she assumes that underneath their oppression, women have some true essence, or essences, which only need to be discovered. She speaks of "women's point of view" (p. 88, 160; see also p. 91), "woman's voice" (p. 195), woman's "distinctive contribution" (p. 123), of standards that are "not ours" (p. 76), of empowering women "on our own terms" (pp. 22, 228), and of what we "really want" (p. 83). These references all suggest a reality beyond social construct that women will discover once freed from the bonds of oppression.

MacKinnon's faith in some authentic reality of womanhood that will emerge once women have thrown off the yoke of male domination is in direct contradiction to her heavy reliance upon the role of social construction in explaining male hegemony. ${ }^{12}$ MacKinnon understands that control over defining what women want is how men have been able to dominate them for so long. By ignoring the importance of what will replace male hegemony, however, she fails to carry forward that understanding. Freedom from social construction and perspective, as MacKinnon should realize, is impossible. Although our perspectives may shift (and the insights MacKinnon provides to us may influence many of us to shift them), we cannot transcend perspective; ${ }^{13}$ for that matter, neither can the men who now dominate us. ${ }^{14}$ The individual man (or woman) who freely chooses his (or her) destiny from some

12. Throughout the book, MacKinnon repeatedly returns to the idea that "[o]ur issue is not the gender difference, but the difference gender makes, the social meaning imposed upon our bodies" (p. 23; see also pp. 25, 54, and 86-87). She develops this idea in her critique of pornography as a force that shapes social reality, that "constructs women and sex, defines what 'woman' means and what sexuality is, in terms of each other" (p. 161; see also pp. 129, 147, 149, 154-55, 160-66, and 173).

13. Stanley Fish persuaded me that one cannot transcend one's perspective, in a course entitled "Professionalism, Theory and Power in Legal and Literary Studies" that 1 attended at Duke Law School in the spring of 1987. Professor Fish has expressed this view most recently in Fish, Still Wrong After All These Years, 6 LAw \& PHIL. 401 (1987) (review of Ronald Dworkin's Law's Empire).

14. MacKinnon also ignores the possibility that men have as little choice as women about what they have come to believe. But if we were to take seriously the notion of social construction, we would have to conclude that this is so. MacKinnon, for example, speaks of the oppression of heterosexuality, notwithstanding the pleasure women think they get out of it (pp. 60-61); can we say that men, even though they think they benefit from heterosexuality, choose it any more willingly? See Flax, Postmodernism and Gender Relations in Feminist Theory, 12 SIGNS: J. WOMEN CUI.TURE \& Soc'Y 621, 629 (1987) ("That men appear to be and (in many cases) are the wardens, or at least the trustees within a social whole, should not blind us to the extent to which they, too, arc governed by the rules of gender."). 
Archimedean vantage point is an invention of liberal ideology. MacKinnon rejects liberal ideology because its assumptions do not apply to women in our society; yet her assumption that achieving parity of power with men will enable women to freely determine and choose what we want suggests that at some deeper level she retains allegiance to this ideology.

Because of MacKinnon's apparent belief in the ability of women to exercise their own free wills once they have power, she fails to see the relevance and immediacy of the question of what women should want for themselves. This failure is the most serious weakness in her theory. If reality is in a continuous process of construction, we should join in that process. Now, as women are coming to understand the true extent of their oppression and taking steps to end it (thanks, in part, to MacKinnon), is when we need to decide who we want to be and what kind of world we are going to construct. Are we going to duplicate the world men have created, where power and advantage for their own sake are the ends we seek? Or do we want something else with the power we achieve? ${ }^{15}$ Is there a different world we would help shape where it is not power (or the absence thereof) that defines us?

The question of vision is not only an important moral question, but also an intensely practical one, for what we intend to do with power affects the terms upon which we acquire it. Let's take the example of child custody, one of the many issues that divides persons calling themselves feminists. ${ }^{16}$ MacKinnon comments that under gender-neutral rules achieved from the "success" of liberal feminism, the law of child custody has been transformed, giving men the advantage of gender-neutral rules without regard to the fact that these principles are stacked against women from the beginning (p. 35). Even if this observation were true, it would only be a statement of fact. Knowing what to do with this

15. This question is not unlike the question she puts to the Santa Clara Pueblo in her talk about a challenge to a tribal rule preventing voting and inheritance rights to children of women who married outside the tribe but not to children of men who married outside the tribe. The rule was adopted by the tribe in order to prevent tribal land from passing out of the tribe. MacKinnon asks whether in responding to this outside danger, the Pueblo are willing to settle for supremacist white male standards, or whether they were going to adopt their own distinctive (and impliedly more equitable) solutions (pp. 63-69).

16. Compare Bartlett \& Stack, Joint Custody, Feminism and the Dependency Dilemma, 2 BERKELEY WOMEN'S L.J. 9 (1986) (arguing against premature abandonment of joint custody as a feminist goal); Klaff, The Tender Years Doctrine: A Defense, 70 CALIF. L. REv. 335 (1982) (arguing for materual presumption rule); Polikoff, Why Are Mothers Losing: A Brief Analysis of Criteria Used in Child Custody Determinations, 7 Women's RTS. L. REP. 235 (1982) (arguing for primary caretaker presumption); Schulman \& Pitt, Second Thoughts on Joint Child Custody: Analysis of Legislation and Its Implications for Women and Children, 12 GoldEN GATE U.L. REV. 538 (1982) (arguing against joint custody preferences); and Uviller, Fathers' Rights and Feminism: The Maternal Presumption Revisited, 1 HARv. WOMEN's L.J. 107 (1978) (arguing for maternal presumption rule). 
fact requires some vision of the society and social relations we want to create. If our objective is to regain and enhance our previous advantage in child custody-to get power wherever we can-we should probably try to reinstitute custodial preferences for women. If, on the other hand, we envision a society in which men and women both build relationships with children based on values of nurturing and responsibility for others, we might conclude that "explicit" legal child custody preferences for mothers would be counterproductive. ${ }^{17}$

MacKinnon's position on the first amendment has similar difficulties. In her view, the first amendment is an instrument of male supremacy because it disguises acts of sexual dominance and violence against women as mere speech (pp. 129-31, 140-41, 146-62). ${ }^{18}$ But if so, what, if any, expression about sexuality or violence should be allowed? When women are given their voice, will they be allowed to speak whatever they want?

If no effort is made at reconstructing our values along with our acquisition of power, what will keep us from being as corrupted-indeed, as male-as the men who now control us? Our strategy for changing the reality she describes must be informed by the kind of future we want to build. As she herself recognizes with respect to male power, "technique is never pure means" (p. 143). Without a theory (however tentative) about our future, it is hard to imagine that any gains made by women will change anything other than our relative positions in a world that continues to value, hunger and fight for power and autonomy.

\section{III}

A theory of care offers one alternative for reconstructing our society on terms beyond those described by MacKinnon's theory of power. As developed most elaborately by Carol Gilligan, the ethic of care is both a methodology and a set of normative values. As a methodology, an ethic of care supplants the formal and abstract thinking entailed in the liberal ethic of justice and rights with an approach to moral problems that is contextual and narrative. Concrete circumstances, the actual situations

17. Bartlett \& Stack, supra note 16.

18. MacKinnon has inspired a lively debate about pornography and the first amendment. See Brest \& Vandenberg, Politics, Feminism, and the Constitution: The Anti-Pornography Movement in Minneapolis, 39 STAN. L. REV. 607 (1987) (describing the drive to enact MacKinnon and Dworkin's antipornography ordinance); Emerson, Pornography and the First Amendment: A Reply to Professor MacKinnon, 3 YALE L. \& Pol'Y REV. 130 (1984) (arguing against the ordinance); Stone, AntiPornography Legislation as Viewpoint-Discrimination, 9 HARV. J.L. \& PUB. POL'Y 461, 480 (1986) (arguing that antipornography ordinance "strikes at the . . . core of . . . First Amendment jurisprudence"); Sunstein, Pornography and the First Amendment, 1986 Duke L.J. 589 (1986) (defending the constitutionality of the antipornography ordinance). See also American Booksellers Ass'n v. Hudnut, 771 F.2d 323 (7th Cir. 1985) (holding antipornography ordinance unconstitutional), aff'd, $106 \mathrm{~S}$. Ct. 1172 (1986). 
of people's lives, their relations to others and their moral characters, rather than abstract principles based upon assumed conditions (such as free individual choice), are the critical components of reasoning based upon an ethic of care. Substantively, an ethic of care suggests a revaluation of the activities of nurture and care. "This conception of morality as concerned with the activity of care centers moral development around the understanding of responsibility and relationships, just as the conception of morality as fairness ties moral development to the understanding of rights and rules." 19 Under an etlic of care, connections between people are valued over the freedom of individuals to act as they wisli so long as they don't hurt anyone else.

Gilligan's development of an ethic of care has been criticized on many grounds, among them, that in finding the etlic of care to be gender-related, she lias helped to maintain the status quo in whicli women's role is to care for others while men do more important things. ${ }^{20}$ Along these lines, MacKinnon criticizes Gilligan for taking the characteristics assigned by men to women and calling tliem ours "rather than what male supremacy has attributed to us for its own use" (pp. 38-39).

The ethic of care is, to be sure, still in its early and searching stages of development. The fact that it still is conceived largely as a female theory, to supplement rather than replace the current value systems built around male control, ${ }^{21}$ is a weakness in the theory. Linked to gender, sucl a theory is likely to continue to legitimate women's powerlessness and passivity to their own oppression, rather than to inspire resistance to that oppression (p. 39). But as a substitute for abstract (male) theories of justice, it may be a useful starting point through which we may revalue, not submerge, whatever characteristics and values we deem worth revaluing. Otlierwise we may become, like MacKinnon describes lierself and otlier feminists, "survivors" (p. 131), but on terms that appear suspiciously "male." 22

Let us take tlie male need to be superior to women. This need makes it impossible for a man to accept a woman who is smarter and more aggressive than he is or who makes more money than he does.

19. C. Gilligan, In a Different Voice: Psychological Theory and Women's DEVELOPMENT 19 (1982).

20. See Tronto, Beyond Gender Difference to a Theory of Care, 12 SIGNS: J. WoMEN CultuRE \& Soc'Y 644, 645, 648-49 (1987).

21. Joan Tronto makes the clearest statement on behalf of further development of a theory of care not based on gender difference. See id. at 652-63.

22. An ethic of care may also lead us to different strategies for change that are more accepting of others than Mackinnon appears to be. Nel Noddings, along this line, writes that "we may become dangerously self-righteous when we perceive ourselves as holding a precious principle not held by the other. The other may then be devalued and treated 'differently'. Our ethic of caring will not permit this to happen." N. Noddings, CARING, A Feminine APproach to Ethics AND MORAL EDUCATION 5 (1984). 
Women may decide that we wish to have meaningful relationships with men, relationships based not on domination but on values of responsibility, caring, and mutual respect (granted this wish may itself be later exposed for some limitation in perspective)-in fleeting glimpses, MacKinnon appears to share this goal (pp. 23, 217). To achieve it, it will not be enough that we succeed in overcoming our impulse to satisfy men; that we become as smart, aggressive, and wealthy as we can; that we wake up and seize whatever power we can; that we beat men at their own game. ${ }^{23}$ Rather, we will want to transform the socially constructed need of men to feel superior (and the consequent need of women to be inferior). We need to reconstruct values that allow us to accept each other on terms other than those of power and advantage. A vision of relationship transformed in this way may help us, as we wrench men's feet off our necks, toward being more than either man or woman has been before.

MacKinnon believes that women should not define what they want narrowly, not just settle for a little corner (pp. 227-28). But her ambitious goal- "no more of this" (p. 227)-is made less rather than more likely by the absence of a fuller vision. Our ability to change the way things are is limited by the absence of values that are themselves transformative. Transformation of our values must coincide with and stimulate the undoing of our system of gender-based oppression. These cannot be separate steps. Alas, neither is likely to occur without the other.

23. At one point, MacKinnon suggests that it is inevitable, and not a bad thing, for women to use power in the way men have used it (p. 220). 